\title{
Towards high-performance tubular-type protonic ceramic electrolysis cells with all-Ni-based functional electrodes
}

\author{
Artem Tarutin ${ }^{\mathrm{a}, \mathrm{b}}$, Anna Kasyanova ${ }^{\mathrm{a}, \mathrm{b}}$, Julia Lyagaeva ${ }^{\mathrm{a}, \mathrm{b}}$, Gennady Vdovin ${ }^{\mathrm{a}}$, \\ Dmitry Medvedev ${ }^{\mathrm{a}, \mathrm{b}, *}$ \\ a Laboratory of Electrochemical Devices Based on Solid Oxide Proton Electrolytes, Institute of High Temperature Electrochemistry, Yekaterinburg 620137, \\ Russia \\ ${ }^{\mathrm{b}}$ Ural Federal University, Yekaterinburg 620002, Russia
}

\section{A R T I C L E I N F O}

\section{Article history:}

Received 2 January 2019

Revised 31 January 2019

Accepted 22 February 2019

Available online 6 March 2019

\section{Keywords:}

Steam electrolysis

Hydrogen production

PCECS

Proton-conducting electrolytes

$\mathrm{Ln}_{2} \mathrm{NiO}_{4}$

\begin{abstract}
A B S T R A C T
Protonic ceramic electrolysis cells (PCECs), which permit high-temperature electrolysis of water, exhibit various advantages over conventional solid oxide electrolysis cells (SOECs), including cost-effectiveness and the potential to operate at low-/intermediate-temperature ranges with high performance and efficiency. Although many efforts have been made in recent years to improve the electrochemical characteristics of PCECs, certain challenges involved in scaling them up remain unresolved. In the present work, we present a twin approach of combining the tape-calendering method with all-Ni-based functional electrodes with the aim of fabricating a tubular-designed PCEC having an enlarged electrode area $\left(4.6 \mathrm{~cm}^{2}\right)$. This cell, based on a $25 \mu \mathrm{m}$-thick $\mathrm{BaCe}_{0.5} \mathrm{Zr}_{0.3} \mathrm{Dy}_{0.2} \mathrm{O}_{3-\delta}$ proton-conducting electrolyte, a nickelbased cermet and a $\operatorname{Pr}_{1.95} \mathrm{Ba}_{0.05} \mathrm{NiO}_{4+\delta}$ oxygen electrode, demonstrates a high hydrogen production rate (19 $\mathrm{mL} \mathrm{min} \mathrm{m}^{-1}$ at $600{ }^{\circ} \mathrm{C}$ ), which surpasses the majority of results reported for traditional button- or planar-type PCECs. These findings increase the scope for scaling up solid oxide electrochemical cells and maintaining their operability at reducing temperatures.
\end{abstract}

(C) 2019 Science Press and Dalian Institute of Chemical Physics, Chinese Academy of Sciences. Published by Elsevier B.V. and Science Press. All rights reserved.

\section{Introduction}

Oxide materials belonging to the $\mathrm{Ln}_{2} \mathrm{NiO}_{4+\delta}(\mathrm{Ln}=\mathrm{La}, \mathrm{Nd}, \mathrm{Pr}$ ) layered nickelate family are considered as promising for application as oxygen electrodes for intermediate-temperature solid oxide fuel cells (IT-SOFCs) [1-5]. The increasing attention paid to such materials is due to the combination of thermal characteristics (low thermal expansion coefficient values and imperceptible chemical expansion [6-8]) and electrocatalytic properties (high surface exchange constant and diffusion coefficient [9-11]), which ensure an excellent adhesive quality of the electrode/electrolyte interface with simultaneous improvement of electrode kinetics.

Despite the fast oxygen mobility of the nickelates and corresponding electrochemical activity favouring oxygen reduction reaction, they are also considered as possible electrodes for protonic ceramic fuel cells (PCFCs), in which proton-involving electrochemical reactions occur at the both electrodes [12-15]. In a

\footnotetext{
* Corresponding author at: Laboratory of Electrochemical Devices Based on Solid Oxide Proton Electrolytes, Institute of High Temperature Electrochemistry, Yekaterinburg 620137, Russia.

E-mail address: dmitrymedv@mail.ru (D. Medvedev).
}

pioneering work, Grimaud et al. [16] have demonstrated improvements in electrode performance for a $\mathrm{Ln}_{2} \mathrm{NiO}_{4}\left|\mathrm{Ba}(\mathrm{Ce}, \mathrm{Zr}) \mathrm{O}_{3}\right| \mathrm{Ln}_{2} \mathrm{NiO}_{4}$ symmetrical cell under humidified air atmosphere. These results correspond to indirect evidence of possible proton transportation, which would allow the nickelates to be considered as examples of triple-conducting materials. Such a transport phenomenon of $\mathrm{Ln}_{2} \mathrm{NiO}_{4+\delta}$ has also been supported in a number of subsequent works $[17,18]$ devoted to the functionality of PCFCs as well as proton ceramic electrolysis cells (PCECs). It should be noted that increased humidification of air is unfavourable for PCFCs from the viewpoint of thermodynamic factors; however, conversely, it is necessary for carrying out steam electrolysis in PCECs $[19,20]$. Therefore, utilising the nickelates in PCECs meets the current trends in research and development of highly performance and efficient protonic ceramic electrochemical cells.

Although some operability issues of PCECs with $\mathrm{Ln}_{2} \mathrm{NiO}_{4+\delta^{-}}$ based electrodes have recently been revealed [17,21-24], the existing results were obtained for planar-type cells having a relatively small electrode area (not more than $0.5 \mathrm{~cm}^{2}$ ). In pursuing the idea of improving overall performance, we hereby present the results of an experimental fabrication of a tubular-type PCEC having an enlarged effective area along with its subsequent characterisation. 
These results can be useful for the future functional optimisation of PCECs, as well as presenting possibilities for their reproduction at a larger scale.

\section{Experimental}

\subsection{Synthesis of materials}

In order to fabricate the PCEC, a $\mathrm{BaCe}_{0.5} \mathrm{Zr}_{0.3} \mathrm{Dy}_{0.2} \mathrm{O}_{3-\delta}$ (BCZD) electrolyte, its mixture with $\mathrm{NiO}$ in anode powder form, a $\mathrm{Pr}_{1.95} \mathrm{Ba}_{0.05} \mathrm{NiO}_{4+\delta}$ oxygen electrode and $\mathrm{LaNi}_{0.6} \mathrm{Fe}_{0.4} \mathrm{O}_{3-\delta}$ (LNF) current collector were used. The selection of BCZD and LNF materials was a consequence of their target properties, which have been recently studied $[25,26]$. Both of these powders were prepared via a citrate-nitrate combustion synthesis method, using the corresponding nitrates as initial components. The BCZD powder was calcined twice (at $700{ }^{\circ} \mathrm{C}$ for $1 \mathrm{~h}$ and $1050{ }^{\circ} \mathrm{C}$ for $5 \mathrm{~h}$ in static air) to provide carbon-based compound removal and preliminary synthesis; the LNF powder was synthesised at $1000{ }^{\circ} \mathrm{C}$ for $5 \mathrm{~h}$ in static air.

The $\mathrm{Pr}_{1.95} \mathrm{Ba}_{0.05} \mathrm{NiO}_{4+\delta}$ (PBN) material was purposefully designed for this work. The base $\mathrm{Pr}_{2} \mathrm{NiO}_{4+\delta}$ composition was selected due to having the highest (compared with $\mathrm{La}_{2} \mathrm{NiO}_{4+\delta}$ and $\mathrm{Nd}_{2} \mathrm{NiO}_{4+\delta}$ ) electrical conductivity and oxygen diffusion characteristics [9,11], while the slight Ba-doping was carried out to improve the phase stability of the Ruddlesden-Popper phase [6]. PBN was also prepared with the citrate-nitrate technique. Corresponding nitrates were taken in the strictly required amounts and dissolved in distilled water with continuous stirring. Following the complete dissolution of the salts, citric acid was added as a chelating agent in a mole ratio of $2: 1$ to the total metal cations and then an ammonia solution slowly dropped in order to regulate the $\mathrm{pH}$ value of the final solution close to 7 . This solution was heated at $200{ }^{\circ} \mathrm{C}$, achieving combustion and the formation of a highly dispersed powder. The latter was synthesised at $1100{ }^{\circ} \mathrm{C}$ for $5 \mathrm{~h}$ in static air to form the single-phase product. Part of this powder was pressed and sintered at $1400{ }^{\circ} \mathrm{C}$ for $5 \mathrm{~h}$ (static air) in order to study its thermal and electrical properties, while another part was used in a mixture with the electrolyte powder (4:1 weight ratio) to prepare slurry for the functional anode.

\subsection{Characterisation of materials}

The complete characterisation details (phase structure, thermal expansion, electrical conductivity) of the PBN material can be found in the supplementary material.

The microstructural PCEC parameters were analysed using scanning electron microscopy (SEM, TESCAN MIRA 3 LMU microscope [27]) coupled with energy dispersive X-ray analysis (EDX, X-MAX 80 spectrometer).

\subsection{Fabrication and characterisation of the PCEC}

The half-cell of the PCFC was fabricated using a tapecalendering method [28], which consists of preparation of oxide/organic films and their rolling and co-sintering together. Three films were prepared: electrolyte film, cathode functional film $(\mathrm{NiO}: \mathrm{BCZD}=55: 45)$ and cathode supporting film (NiO:BCZD:strach $=65: 35: 20$ ); here, the ratios were presented in weight form. These films were rolled together in a particular way keeping the electrolyte thickness close to $30 \mu \mathrm{m}$. Then the threelayered film was twisted into a tube, slowly heated in static air up to $900{ }^{\circ} \mathrm{C}$ and then co-sintered at $1400{ }^{\circ} \mathrm{C}$ in static air with a soaking time of $3 \mathrm{~h}$.

The PBN slurry was formed onto the electrolyte surface of the as-sintered half-cell using a spraying method followed by sintering at $1000{ }^{\circ} \mathrm{C}$ for $2 \mathrm{~h}$ in static air. Following completion of the sintering procedure, the temperature was increased to $1050{ }^{\circ} \mathrm{C}$ (without soaking) in order to join the prepared PCEC tube with the YSZ supporting tube, from one side, and with the BCZD cap, from the other side. The joining was performed by mean of a borosilicate glass sealant having a melting temperature of $\sim 1050{ }^{\circ} \mathrm{C}$. This sealant was also distributed across the junction of the films to prevent gas mixing.

In order to improve current distribution across the surface of the electrode and reduce its in-plane resistance, the LNF composition was utilised: it was sprayed onto the surface of the PBN anode functional layer followed by calcination at $900{ }^{\circ} \mathrm{C}$ in static air. The total active area of the tube was estimated to be equal $4.6 \mathrm{~cm}^{2}$. The platinum wires were wound in a spiral form onto the outer part of the PCEC tube, while a Ni-wool was used in the inner part. The current collection between the electrochemical cell and the measurement equipment was organised by means of platinum wires (in the hot zone) and copper wires (in the cold zone).

The PCEC was characterised using a special fabricated measurement cell (see Appendix A, Fig. A1). This cell was heated up to required temperatures $\left(500,600\right.$ or $\left.700{ }^{\circ} \mathrm{C}\right)$ feeding the inner electrode by wet hydrogen and the outer electrode by wet air with the corresponding flow rates of 150 and $400 \mathrm{~mL}$. Partial water vapour pressures in reducing and oxidising atmospheres were equal to 0.03 and $0.30 \mathrm{~atm}$, respectively. The temperature values were setting by a Zirconia-318 microprocessor, which also allows managing the reducing atmosphere composition in respect to the reference wet air atmosphere (in terms of oxygen partial pressure difference). The electrochemical characterisation was carried out using an Amel 2550 potentiostat/galvanostat and a MaterialsM 520 frequency response analyser. The volt-ampere curves were recorded from open circuit voltage values to $2 \mathrm{~V}$ with a voltage step of $20 \mathrm{mV}$. The impedance spectra were measured in a frequency range of $10^{-1}-10^{5} \mathrm{~Hz}$ at three biases (open circuit voltage, 1.3 and $1.6 \mathrm{~V}$ ) with an amplitude signal of $20 \mathrm{mV}$. The spectra were analysed using Zview software and the distribution of relaxation time procedure using the DRTtools core of the Matlab software.

\section{Results and discussion}

\subsection{Individual properties of $\mathrm{Pr}_{2} \mathrm{NiO}_{4}$-based material}

Before the application of PBN as anode material in the PCEC, its structural, thermomechanical and electrical characteristics were thoroughly studied. These results can be found in supplementary material.

\subsection{Design and electrochemical performance of the PCEC}

\subsubsection{Microstructure of the PCEC}

Fig. 1 shows the microstructural features of the tubular-type PCEC. The length of the experimental cell was equal to $1.8 \mathrm{~cm}$, while the average external diameter was equal to $0.97 \mathrm{~cm}$. The electrode area was estimated at $4.6 \mathrm{~cm}^{2}$. The cell prepared by the tape-calendering method was completely gas-tight (determined by a soaking method) due to careful gluing of the film's junction (Fig. 1d), although a slight deformation in the diameter of the tube can be distinguished (Fig. 1b). The total thickness of the multi-layered film reached $700 \mu \mathrm{m}$ (Fig. 1c,d), while the thickness of the LNF current collector, PBN functional anode, BCZD electrolyte and NiO-BCZD functional cathode layers were found to be around 25, 18, 25 and $25 \mu \mathrm{m}$, respectively (Fig. 1e). As shown from Fig. 1(e,f), all the functional materials were well-adhered and quite homogeneous.

\subsubsection{Open circuit voltage mode}

The operation mode of the PCEC under open circuit voltage (OCV) conditions is very useful, since it allows the formation of conclusions concerning the integrity of the system and transport 

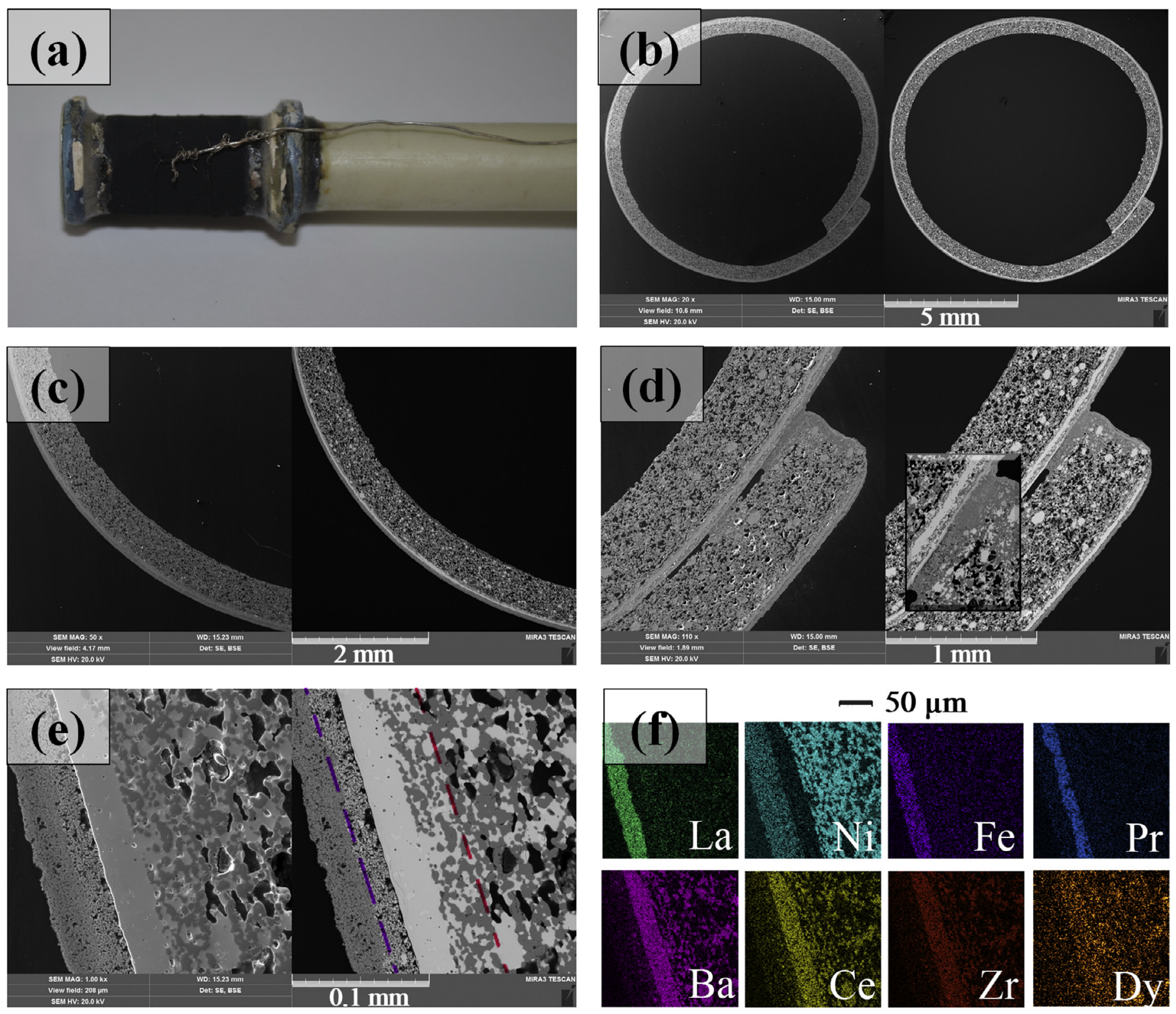

\section{$50 \mu \mathrm{m}$}
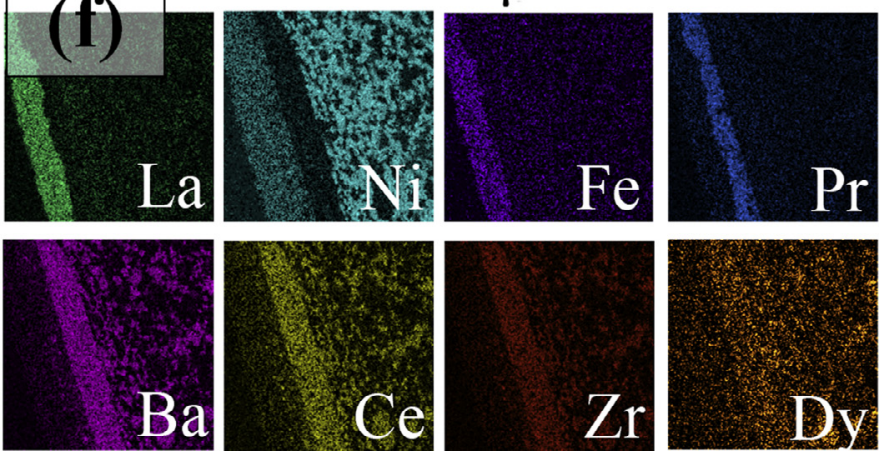

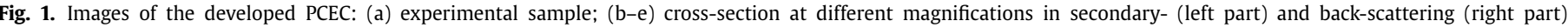
electron modes, including the general view (b) and the glued section (d); (f) cation distribution maps of the cross-section (e).

behaviour of the electrolyte membrane. Since the studied cell represents an element with quite a large active area, OCVs should be considered as particular average values.

According to Fig. 2, the generated OCV values amount about $1.08,1.02$ and $0.94 \mathrm{~V}$ at 500,600 and $700{ }^{\circ} \mathrm{C}$, respectively. On the basis of the achieved and theoretically-predicted OCV values, it is possible to estimate the electrolytic properties of BCZD.

Generally, a cell with a hypothetical triple-conducting material is able to generate the electrical voltage difference $\left(E_{\text {meas }}\right)$, which can be expressed in an analytical form as $[29,30]$ :

$$
E_{\text {meas }}=t_{\mathrm{O}} \frac{R T}{4 F} \ln \left(\frac{p^{\prime} \mathrm{O}_{2}}{p^{\prime \prime} \mathrm{O}_{2}}\right)+t_{\mathrm{H}} \frac{R T}{2 F} \ln \left(\frac{p^{\prime \prime} \mathrm{H}_{2}}{p^{\prime} \mathrm{H}_{2}}\right)=t_{\mathrm{O}} E_{\mathrm{O}}+t_{\mathrm{H}} E_{\mathrm{H}}
$$

where: $R$ is the universal gas constant; $T$ is the absolute temperature; $F$ is the Faraday constant; $p^{\prime} \mathrm{O}_{2}$ and $p^{\prime \prime} \mathrm{O}_{2}$ are the oxygen partial pressures at the anode and cathode sides, respectively; $p^{\prime} \mathrm{H}_{2}$ and $p^{\prime \prime} \mathrm{H}_{2}$ are the hydrogen partial pressures at the same spaces; $t_{\mathrm{O}}$ and $t_{\mathrm{H}}$ are the oxygen-ions and protons transference numbers; and $E_{\mathrm{O}}$ and $E_{\mathrm{H}}$ are the thermodynamic (theoretical) potential values of ideal oxygen-ionic and protonic electrolytes.

In order to additionally consider the electron transfer $\left(t_{\text {electron }}\right)$, Eq. (1) can be expressed as

$$
E_{\text {meas }}=t_{i} \frac{R T}{4 F} \ln \left(\frac{p^{\prime} \mathrm{O}_{2}}{p^{\prime \prime} \mathrm{O}_{2}}\right)+t_{\mathrm{H}} \frac{R T}{2 F} \ln \left(\frac{p^{\prime \prime} \mathrm{H}_{2} \mathrm{O}}{p^{\prime} \mathrm{H}_{2} \mathrm{O}}\right)=t_{i} E_{\mathrm{O}}+t_{\mathrm{H}} E_{\mathrm{H}_{2} \mathrm{O}}
$$

considering the equilibrium of the following reaction:

$\mathrm{H}_{2} \mathrm{O} \rightleftarrows \mathrm{H}_{2}+1 / 2 \mathrm{O}_{2}$

Here $t_{i}$ is the ionic transference number $\left(t_{i}=t_{\mathrm{O}}+t_{\mathrm{H}}, t_{i}=1-\right.$ $\left.t_{\text {electron }}\right)$ and $E_{\mathrm{H}_{2} \mathrm{O}}$ is the potential difference of a waterconcentration cell under the water vapor partial pressure gradient $\left(p^{\prime} \mathrm{H}_{2} \mathrm{O}\right.$ and $\left.p^{\prime \prime} \mathrm{H}_{2} \mathrm{O}\right)$.

Expressing the $t_{i}$ parameter from Eq. (2)

$t_{i}=\frac{E_{\text {meas }}-t_{\mathrm{H}} E_{\mathrm{H}_{2} \mathrm{O}}}{E_{\mathrm{O}}}$ 


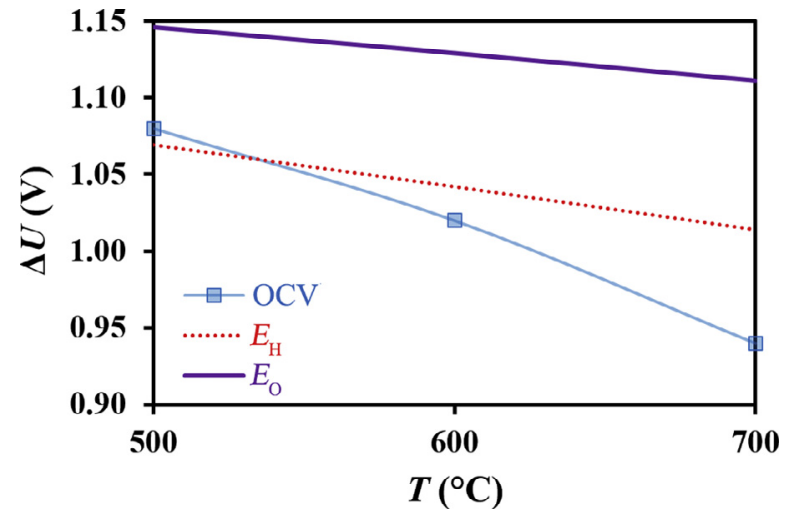

Fig. 2. The OCV values of the PCEC compared with theoretically predicted ones for purely protonic $\left(E_{\mathrm{H}}\right)$ or oxygen-ionic $\left(E_{\mathrm{O}}\right)$ electrolytes.

Table 1. Theoretical and experimental potential difference values and ionic transference number boundary of the BCZD electrolyte under wet air/wet hydrogen conditions with $p^{\prime} \mathrm{H}_{2} \mathrm{O}=0.30 \mathrm{~atm}$ and $p^{\prime \prime} \mathrm{H}_{2} \mathrm{O}=0.03 \mathrm{~atm}$.

\begin{tabular}{llllll}
\hline$T\left({ }^{\circ} \mathrm{C}\right)$ & OCV $(\mathrm{V})$ & $E_{\mathrm{O}}(\mathrm{V})$ & $E_{\mathrm{H}}(\mathrm{V})$ & $t_{i, \min }$ & $t_{i, \max }$ \\
\hline 500 & 1.08 & 1.146 & 1.069 & 0.94 & 1.00 \\
600 & 1.02 & 1.129 & 1.042 & 0.90 & 0.98 \\
700 & 0.94 & 1.111 & 1.014 & 0.85 & 0.93
\end{tabular}

it is possible to determine the ionic transference numbers boundary of the BCZD electrolyte. A degree of uncertainty in the analysis is associated with that fact that Eq. (2) has two independent parameters $\left(t_{\mathrm{i}}\right.$ and $\left.t_{\mathrm{H}}\right)$, when other parameters $\left(E_{\text {meas }}=\mathrm{OCV}, E_{\mathrm{O}}\right.$ and $\left.E_{\mathrm{H}_{2} \mathrm{O}}\right)$ are known. Nevertheless, the $t_{i}$ and $t_{\mathrm{H}}$ parameters can be estimated. This is realised by setting the $t_{\mathrm{H}}$ values in a rational range (with a step of $\Delta t_{\mathrm{H}}=0.01$ ), then calculating $t_{i}$ and considering the boundary conditions: $0 \leq t_{j} \leq 1$ (where $j=0, \mathrm{H}, i$ ) and $t_{\mathrm{H}} \leq t_{i}, t_{\mathrm{O}} \leq t_{i}$. The results of the performed analysis are presented in Table 1 . In this table, the $t_{i, \min }$ values correspond to the condition of $t_{\mathrm{H}}=0.01$, while the $t_{i, \max }$ values are related to the condition of $t_{i}=t_{\mathrm{H}}$.

It is well-known that materials based on barium ceratezirconates are predominantly proton conductors under humid conditions at $500-700{ }^{\circ} \mathrm{C}\left(t_{0}<0.1-0.2\right.$ [31-33]), which allows the ionic transference numbers at the second boundary $\left(t_{i, \max }\right)$ to be considered as the most reliable data. Indeed, these values are in close relation with those obtained for the PCEC or PCFC with similar electrolytes [28,34]. Therefore, the electrolyte membrane in the tubular form maintains its electrolytic characteristic and gastightness of the whole tube.

\subsubsection{Performance of the PCEC}

Fig. 3 shows the results of the electrochemical testing presented for the tubular-type PCEC. As can be seen, the cell yields current densities as high as $1.80,2.37$ and $2.68 \mathrm{~A} \mathrm{~cm}^{-2}$ at 500, 600 and $700{ }^{\circ} \mathrm{C}$ at $2.0 \mathrm{~V}$ of the bias. Under the thermoneutral mode $\left(U_{\text {tn }}=\sim 1.3 \mathrm{~V}\right.$ at $\left.600-900{ }^{\circ} \mathrm{C}\right)$, the current densities reach $0.37,0.61$ and $0.85 \mathrm{~A} \mathrm{~cm}^{-2}$, respectively; this mode is convenient from the real operational point of view since it corresponds to the condition when heat is not consumed (OCV $\left.<U<U_{\mathrm{tn}}\right)$ or released $\left(U>U_{\mathrm{tn}}\right)$ at electrical-to-chemical energy conversion [35,36].

Considering ionic transference numbers to be responsible for the useful part of the energy conversion, the maximal achievable specific and overall hydrogen fluxes can be calculated as

$j \mathrm{H}_{2}=\frac{i}{2 F} \cdot t_{i}$

$J \mathrm{H}_{2}=\frac{i}{2 F} \cdot S \cdot t_{i}$ where $S$ is the effective electrode area of the tube.

For the studied PCEC, the $\mathrm{JH}_{2}$ is equal about 12, 19 and $25 \mathrm{~mL} \mathrm{~min}^{-1}$ at 500, 600 and $700{ }^{\circ} \mathrm{C}$, respectively (inset in Fig. 3b). These values, as shown in Table $2[17,23,37-42]$, are exceptionally high compared with the previously obtained results reported for the single PCECs (with the exception of those featured in the work of Marrony and Dailly [39], where a planar-type cell was fabricated in an effective electrode area of $16 \mathrm{~cm}^{2}$ ). Considering the hydrogen flux densities (Fig. A2), they are higher for the PCECs with lower S, which can be explained by a better current distribution across the short distance of the oxygen electrodes $(0.5-0.8 \mathrm{~cm}$ in their diameter). Moreover, using nanostructured composite materials (for example, NBSCF-BZCYYb), such densities can reach promising levels [42]. In the case of the enlarged active area, the current is limited by the increased in-plane resistance, even if the electrodes demonstrate a superior activity for the model cells. This problem was partially resolved using the LNF current collector, which exhibits very high electronic conductivity even in the porous state $[13,43]$. Comparing together such parameters as the hydrogen fluxes and their densities, it can be stated that the studied cell represents a rational compromise between these output characteristics.

\subsubsection{Electrochemical activity of $\mathrm{Pr}_{2} \mathrm{NiO}_{4+\delta}$-based electrode}

In order to evaluate the potential utility of the $\operatorname{Pr}_{1.95} \mathrm{Ba}_{0.05} \mathrm{NiO}_{4+\delta}$ anode, electrochemical impedance spectroscopy (EIS) analysis was employed, Fig. 4. It was found that the spectral shape changes considerably with variations in the temperature $(T)$ and applied voltage $(U)$. In details, at the first glance, the spectra represent one predominant process (one depressed semicircle) at high $T$ and $U$ parameters and at least three distinguished electrode processes at lower $T$ and $U$. With the aim of determining the total polarisation resistance $\left(R_{p}\right)$ and its partial components $\left(R_{1}, R_{2}\right.$ and $R_{3}$ ), these spectra were fitted by the model curves corresponding to the $L-R_{0}-R_{1} Q_{1}, L-R_{0}-R_{1} Q_{1}-R_{2} Q_{2}$ or $L-R_{0}-R_{1} Q_{1}-R_{2} Q_{2}-$ $R_{3} Q_{3}$ equivalent circuits (where $L$ is the inductance associated with wires and connection cables, $Q$ is the constant phase element [44]). However, the theoretical data were fitted to the experimental results only for the curves with virtually one- and two-type processes. The remaining curves were not described correctly with the proposed models due to a high difference error, exceeding $200 \%$ for the fitting parameters $\left(R_{j}, Q_{j}, n_{j} ; j=1,2\right.$ or 3$)$.

To overcome this arising problem, the alternative procedure distribution of relaxation time (DRT) $[45,46]$ - was successfully adopted. As can be seen from Fig. 5, the rate-limiting relaxation processes can clearly be separated for all the conditions used. In detail, two or three regions may be identified across a wide frequency range.

The correlation of the peaks with the corresponding electrode processes was performed using available data for similar protonic ceramic electrochemical cells as well as characteristic frequency values (Table 3, [47-49]).

More precisely, the low frequency peaks are typically associated with gas adsorption/desorption and gas diffusion in the porous electrodes. Since the diffusion of hydrogen molecules in the porous media of the cermet is much faster than mass transfer of water in the anode, this peak should be related to a water-involved process. Indeed, as shown in additionally performed experiments with different air humidity levels (Fig. A3), the intensity of the lowfrequency peak decreases considerably with variation in $\mathrm{pH}_{2} \mathrm{O}$. This indicates that air humidification promotes enriching of the interface region by water molecules acting as reactants for electrolysis.

The low frequency processes (below $\sim 10^{2} \mathrm{~Hz}$ ) disappear when the applied voltage increases. This does not imply kinetic limitations in gas adsorption or molecular diffusion under electrolysis due to the bias acting as an electromotive force. 

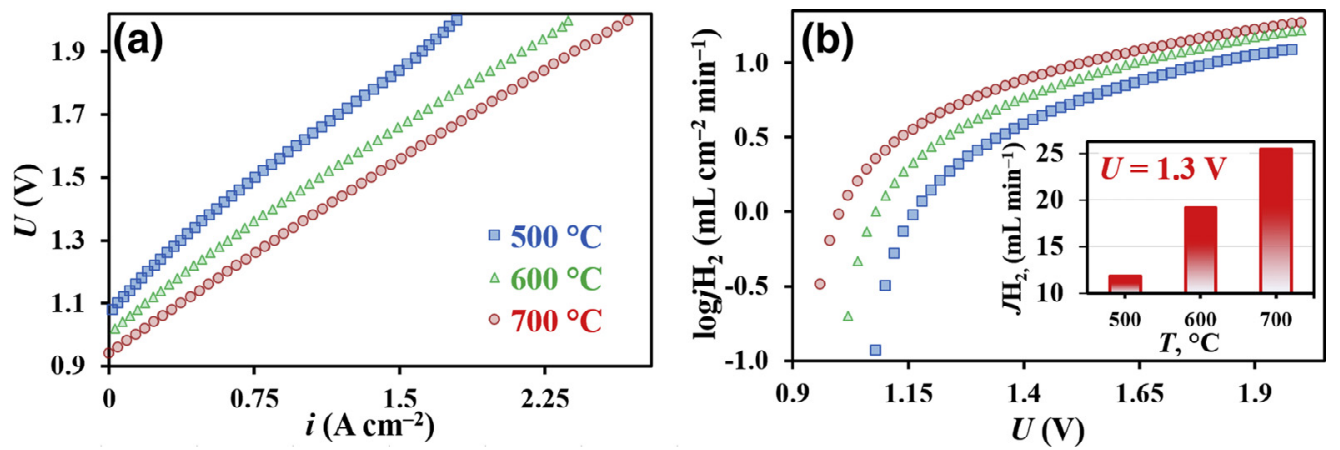

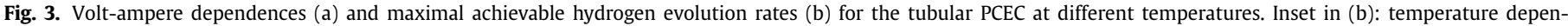
dence of maximal achievable hydrogen flux under thermoneutral mode conditions.

Table 2. Comparative analysis of the unit protonic ceramic electrolysis cells at an operation voltage of $1.3 \mathrm{~V}$.

\begin{tabular}{|c|c|c|c|c|c|c|c|}
\hline Cathode & $\begin{array}{l}\text { Electrolyte }^{\mathrm{a}} \\
\text { (thickness) }\end{array}$ & Anode $^{\mathrm{b}}$ (electrode area) & $\begin{array}{l}\text { Reducing/oxidising } \\
\text { atmospheres }\end{array}$ & $T\left({ }^{\circ} \mathrm{C}\right)$ & $j \mathrm{H}_{2}{ }^{\mathrm{c}}\left(\mathrm{mL} \mathrm{min} \mathrm{m}^{-1} \mathrm{~cm}^{-2}\right)$ & $J \mathrm{H}_{2}{ }^{\mathrm{c}}\left(\mathrm{mL} \mathrm{min}^{-1}\right)$ & Ref. \\
\hline \multirow[t]{3}{*}{$\mathrm{Ni}-\mathrm{BCZD}$} & $\mathrm{BCZD}(25 \mu \mathrm{m})$ & PBN-BCZD $\left(4.6 \mathrm{~cm}^{2}\right)$ & $3 \% \mathrm{H}_{2} \mathrm{O}-\mathrm{H}_{2} / 30 \% \mathrm{H}_{2} \mathrm{O}$-air & 500 & 2.6 & 12 & This work \\
\hline & & & & 600 & 4.4 & 20 & \\
\hline & & & & 700 & 5.9 & 27 & \\
\hline \multirow[t]{3}{*}{$\mathrm{Ni}-\mathrm{BCZY}$} & $\mathrm{BCZY}(15 \mu \mathrm{m})$ & $\operatorname{SEFC}\left(0.24 \mathrm{~cm}^{2}\right)$ & $3 \% \mathrm{H}_{2} \mathrm{O}-\mathrm{H}_{2} / 10 \% \mathrm{H}_{2} \mathrm{O}$-air & 600 & 2.5 & 0.6 & [37] \\
\hline & & & & 650 & 5.0 & 1.2 & \\
\hline & & & & 700 & 7.1 & 1.7 & \\
\hline \multirow[t]{2}{*}{$\mathrm{Ni}-\mathrm{BCZY}$} & $\mathrm{BCZY}(15 \mu \mathrm{m})$ & $\operatorname{LSN}\left(0.25 \mathrm{~cm}^{2}\right)$ & $3 \% \mathrm{H}_{2} \mathrm{O}-\mathrm{H}_{2} / 20 \% \mathrm{H}_{2} \mathrm{O}$-air & 600 & 2.8 & 0.7 & [23] \\
\hline & & & & 700 & 9.6 & 2.4 & \\
\hline \multirow[t]{2}{*}{$\mathrm{Ni}-\mathrm{BCZY}$} & $\mathrm{BCZY}(15 \mu \mathrm{m})$ & $\operatorname{PSN}\left(0.25 \mathrm{~cm}^{2}\right)$ & & 600 & 2.4 & 0.6 & \\
\hline & & & & 700 & 8.0 & 2.0 & \\
\hline \multirow[t]{3}{*}{$\mathrm{Ni}-\mathrm{BCZY}$} & $\mathrm{BCZY}(16 \mu \mathrm{m})$ & $\operatorname{LSN}\left(0.25 \mathrm{~cm}^{2}\right)$ & $3 \% \mathrm{H}_{2} \mathrm{O}-\mathrm{H}_{2} / 20 \% \mathrm{H}_{2} \mathrm{O}$-air & 600 & 2.0 & 0.5 & [38] \\
\hline & & & & 650 & 5.2 & 1.3 & \\
\hline & & & & 700 & 8.8 & 2.2 & \\
\hline $\mathrm{Ni}-\mathrm{BCZY} 1$ & BCZY1 $(15 \mu \mathrm{m})$ & BSCF-BCZY1 $\left(16 \mathrm{~cm}^{2}\right)$ & $3 \% \mathrm{H}_{2} \mathrm{O}-\mathrm{H}_{2} / 20 \% \mathrm{H}_{2} \mathrm{O}$-air & 700 & $2.1^{\mathrm{d}}$ & $33^{d}$ & [39] \\
\hline \multirow[t]{4}{*}{$\mathrm{Ni}-\mathrm{BCZY2}$} & BCZY2 $(20 \mu \mathrm{m})$ & PSN1-BCZY2 $\left(0.5 \mathrm{~cm}^{2}\right)$ & dry $\mathrm{H}_{2} / 40 \% \mathrm{H}_{2} \mathrm{O}$-air & 550 & 1.4 & 0.7 & [17] \\
\hline & & & & 600 & 2.4 & 1.2 & \\
\hline & & & & 650 & 4.2 & 2.1 & \\
\hline & & & & 700 & 6.6 & 3.3 & \\
\hline $\mathrm{Ni}-\mathrm{SZCY}$ & SZCY $(12 \mu \mathrm{m})$ & $\operatorname{BLC}\left(0.51 \mathrm{~cm}^{2}\right)$ & $2 \% \mathrm{H}_{2} \mathrm{O}-\mathrm{H}_{2} / 1 \% \mathrm{O}_{2}+80 \% \mathrm{H}_{2} \mathrm{O}$-air & 600 & 1.4 & 0.7 & {$[40]$} \\
\hline $\mathrm{Ni}-\mathrm{SZCY}$ & SZCY $(17 \mu \mathrm{m})$ & $\operatorname{BLC}\left(0.51 \mathrm{~cm}^{2}\right)$ & & 600 & 1.6 & 0.8 & \\
\hline $\mathrm{Ni}-\mathrm{BCZY3}$ & BCZY3 $(12 \mu \mathrm{m})$ & $\operatorname{BLC}\left(0.51 \mathrm{~cm}^{2}\right)$ & & 600 & 1.6 & 0.8 & \\
\hline $\mathrm{Ni}-\mathrm{BCZY3}$ & BCZY3 $(17 \mu \mathrm{m})$ & $\operatorname{BLC}\left(0.51 \mathrm{~cm}^{2}\right)$ & & 600 & 1.8 & 0.9 & \\
\hline \multirow[t]{3}{*}{$\mathrm{Ni}-\mathrm{BZY}$} & $\mathrm{BZY}(16 \mu \mathrm{m})$ & SFM-BZY $\left(0.33 \mathrm{~cm}^{2}\right)$ & $90 \% \mathrm{~N}_{2}-10 \% \mathrm{H}_{2} / 3 \% \mathrm{H}_{2} \mathrm{O}$-air & 550 & 0.6 & 0.2 & {$[41]$} \\
\hline & & & & 600 & 1.5 & 0.5 & \\
\hline & & & & 650 & 2.4 & 0.8 & \\
\hline \multirow[t]{3}{*}{$\mathrm{Ni}-\mathrm{BZCYYb}$} & $\begin{array}{l}\text { BZCYYb } \\
(20 \mu \mathrm{m})\end{array}$ & NBSCF-BZCYYb $\left(0.36 \mathrm{~cm}^{2}\right)$ & $10 \% \mathrm{H}_{2} \mathrm{O}-\mathrm{H}_{2} / 10 \% \mathrm{H}_{2} \mathrm{O}$-air & 600 & 5.3 & 1.9 & {$[42]$} \\
\hline & & & & 650 & 8.9 & 3.2 & \\
\hline & & & & 700 & 17.2 & 6.2 & \\
\hline
\end{tabular}

${ }^{\mathrm{a}}$ Electrolyte abbreviations: $\quad \mathrm{BCZY}=\mathrm{BaCe}_{0.7} \mathrm{Zr}_{0.1} \mathrm{Y}_{0.2} \mathrm{O}_{3-\delta}, \quad \mathrm{BCZY} 1=\mathrm{BaCe}_{0.8} \mathrm{Zr}_{0.1} \mathrm{Y}_{0.1} \mathrm{O}_{3-\delta}, \quad \mathrm{BCZY}_{2}=\mathrm{BaCe}_{0.6} \mathrm{Zr}_{0.2} \mathrm{Y}_{0.2} \mathrm{O}_{3-\delta}, \quad \mathrm{BCZY}_{3}=\mathrm{BaZr}_{0.44} \mathrm{Ce}_{0.36} \mathrm{Y}_{0.2} \mathrm{O}_{3-\delta}, \quad \mathrm{BCZYYb}=$ $\mathrm{BaZr}_{0.1} \mathrm{Ce}_{0.7} \mathrm{Y}_{0.1} \mathrm{Yb}_{0.1} \mathrm{O}_{3-\delta}, \mathrm{BZY}=\mathrm{BaZr}_{0.8} \mathrm{Y}_{0.2} \mathrm{O}_{3-\delta}, \mathrm{SZCY}=\mathrm{SrZr}_{0.5} \mathrm{Ce}_{0.4} \mathrm{Y}_{0.1} \mathrm{O}_{3-\delta}$;

b Electrode abbreviations: $\quad \mathrm{SEFC}=\mathrm{SrEu}_{2} \mathrm{Fe}_{1.8} \mathrm{Co}_{0.2} \mathrm{O}_{7-\delta}, \quad \mathrm{PSN}_{=} \mathrm{Pr}_{1.2} \mathrm{Sr}_{0.8} \mathrm{NiO}_{4-\delta}, \quad \mathrm{LSN}=\mathrm{La}_{1.2} \mathrm{Sr}_{0.8} \mathrm{NiO}_{4-\delta}, \quad \mathrm{BSCF}=\mathrm{Ba}_{0.5} \mathrm{Sr}_{0.5} \mathrm{Co}_{0.8} \mathrm{Fe}_{0.2} \mathrm{O}_{3-\delta}, \quad \mathrm{PSN}_{1}=\mathrm{Pr}_{1.2} \mathrm{Sr}_{0.8} \mathrm{NiO}_{4-\delta}$, $\mathrm{BLC}=\mathrm{Ba}_{0.5} \mathrm{La}_{0.5} \mathrm{CoO}_{3-\delta}, \mathrm{SFM}=\mathrm{Sr}_{2} \mathrm{Fe}_{1.5} \mathrm{Mo}_{0.5} \mathrm{O}_{6-\delta}, \mathrm{NBSCF}=\mathrm{NdBa}_{0.5} \mathrm{Sr}_{0.5} \mathrm{Co}_{1.5} \mathrm{Fe}_{0.5} \mathrm{O}_{5+\delta}$;

c The hydrogen fluxes are provided without influence of the ionic transference number:

d This value is presented at $1.2 \mathrm{~V}$.
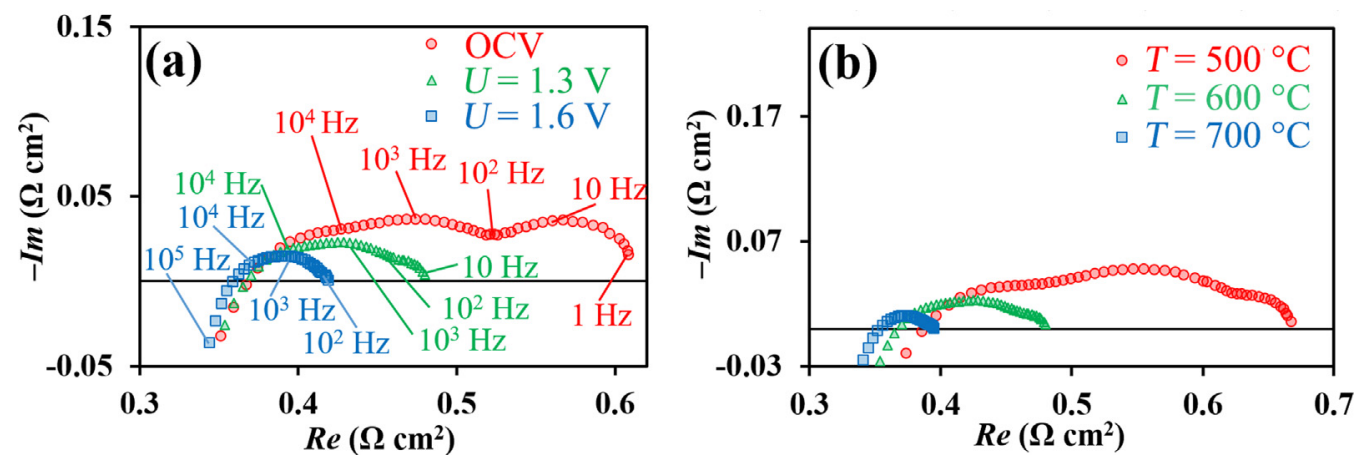

Fig. 4. The typical impedance spectra of the PCEC depending on the bias at $600{ }^{\circ} \mathrm{C}$ (a) and depending on temperature at $1.3 \mathrm{~V}(\mathrm{~b})$. 
Table 3. Elementary steps realised at PCEC electrodes under water electrolysis [47-49].

\begin{tabular}{|c|c|c|c|}
\hline Electrode & Elementary reaction ${ }^{\mathrm{a}, \mathrm{b}}$ & Description & No. \\
\hline \multirow[t]{9}{*}{ Anode frequency incensement $\downarrow$} & $\mathrm{H}_{2} \mathrm{O}_{(\mathrm{g})} \rightleftarrows \mathrm{H}_{2} \mathrm{O}_{(\mathrm{ads})}$ & Water adsorption & 1 \\
\hline & $\mathrm{H}_{2} \mathrm{O}_{(\mathrm{ads})} \rightleftarrows \mathrm{OH}_{(\mathrm{ads})}^{-}+\mathrm{H}_{(\mathrm{ads})}^{+}$ & Water dissociation & 2 \\
\hline & $\mathrm{OH}_{(\mathrm{ads})}^{-} \rightleftarrows \mathrm{O}_{(\mathrm{ads})}^{2-}+\mathrm{H}_{(\mathrm{ads})}^{+}$ & Adsorbed spaces dissociation & 3 \\
\hline & $\mathrm{O}_{(\mathrm{ads})}^{2-}-\mathrm{e}^{-} \rightleftarrows \mathrm{O}_{(\mathrm{ads})}^{-}$ & Oxygen oxidation & 4 \\
\hline & $\mathrm{O}_{(\mathrm{ads})}^{-}-\mathrm{e}^{-} \rightleftarrows \mathrm{O}_{(\mathrm{ads})}$ & Oxygen oxidation & 5 \\
\hline & $\mathrm{O}_{\text {(ads) }} \rightleftarrows \mathrm{O}_{2(\mathrm{ads})}$ & Oxygen association & 6 \\
\hline & $\mathrm{O}_{2 \text { (ads) }} \rightleftarrows \mathrm{O}_{2(\mathrm{~g})}$ & Molecular oxygen formation & 7 \\
\hline & $\mathrm{H}_{(\mathrm{ads})}^{+} \rightleftarrows \mathrm{H}_{(\mathrm{tpb})}^{+}$ & Proton diffusion to TPB & 8 \\
\hline & $\mathrm{H}_{(\mathrm{tpb})}^{+} \rightleftarrows \mathrm{H}_{(\mathrm{el})}^{+}$ & Proton incorporation in lattice & 9 \\
\hline \multirow[t]{4}{*}{ Cathode frequency incensement $\uparrow$} & $\mathrm{H}_{(\mathrm{el})}^{+} \rightleftarrows \mathrm{H}_{(\mathrm{el}, \text { surf })}^{+}$ & Proton diffusion to electrolyte surface & 10 \\
\hline & $\mathrm{H}_{\text {(el,surf) }}^{+} \rightleftarrows \mathrm{H}_{(\mathrm{Ni}, \text { ads })}^{+}$ & Proton transfer through interface & 11 \\
\hline & $\mathrm{H}_{(\mathrm{Ni}, \mathrm{ads})}^{+}+\mathrm{e}^{-} \rightleftarrows \mathrm{H}_{(\mathrm{Ni}, \mathrm{ads})}$ & Hydrogen reduction & 12 \\
\hline & $2 \mathrm{H}_{(\mathrm{Ni}, \mathrm{ads})} \rightleftarrows \mathrm{H}_{2(\mathrm{~g})}$ & Molecular hydrogen formation & 13 \\
\hline
\end{tabular}

a abbreviations: g - gas, ads - adsorbed, tpb - triple phase boundary, el - electrolyte, surf - surface;

b molecular gas diffusion steps are not presented.
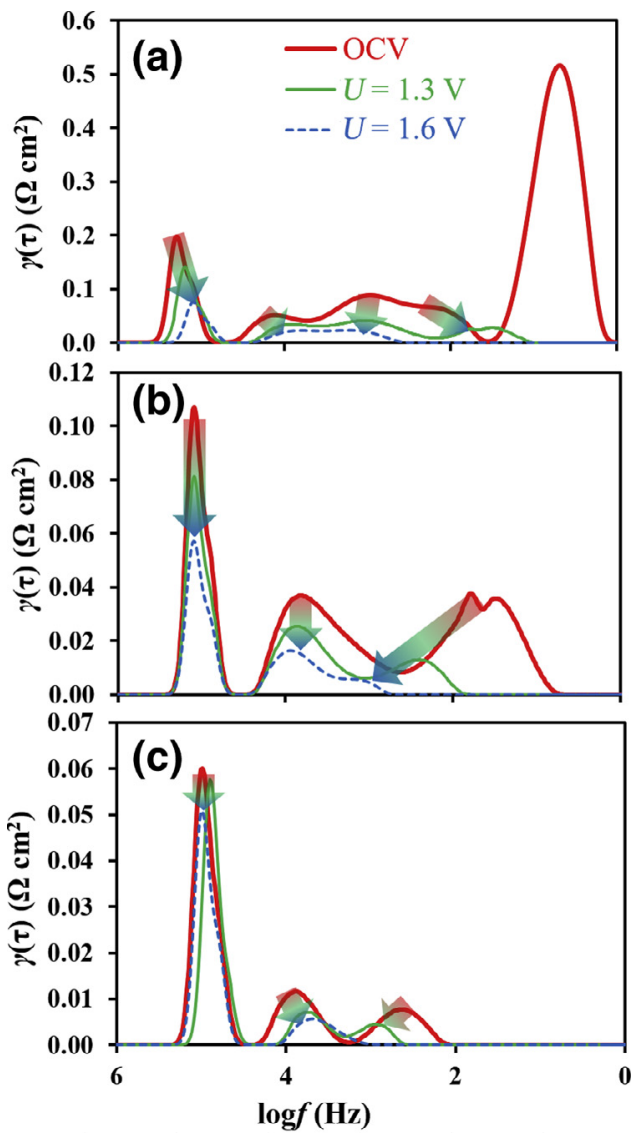

Fig. 5. Frequency-dependent DRT functions of the original spectra (see Fig. 4) obtained at $500{ }^{\circ} \mathrm{C}(\mathrm{a}), 600{ }^{\circ} \mathrm{C}$ (b) and $700{ }^{\circ} \mathrm{C}(\mathrm{c})$.

The medium frequency region $\left(\sim 10^{1.5}-10^{4.5} \mathrm{~Hz}\right.$ at $500^{\circ} \mathrm{C}, 10^{2.5}$ $10^{4.5} \mathrm{~Hz}$ at $600{ }^{\circ} \mathrm{C}$ and $10^{3}-10^{4.5} \mathrm{~Hz}$ at $600{ }^{\circ} \mathrm{C}$ ) is attributed to dissociation/association phenomena and charge transfer stages. At the same time, this complicated region at $500{ }^{\circ} \mathrm{C}$ consists of at least three independent peaks (Fig. 5a), causing the previously mentioned difficulties in the impedance spectra fitting. When temperature is increased, the form of such a medium frequency region starts to become more simplified, evolving into a single, well-resolved peak (Fig. 5c).

Returning to Fig. A3(a), the right part of this region (around $10^{2} \mathrm{~Hz}$ ) is suppressed at $500{ }^{\circ} \mathrm{C}$ under air humidification, implying the facilitation of the electrode process (steps 2, 3); this might be simply explained by shifting the equilibrium of the reactions 1-3 (Table 3) to the right. On the other hand, the intensities (and corresponding resistances) of the other parts are found to increase when $\mathrm{pH}_{2} \mathrm{O}$ changes from 0.03 to $0.3 \mathrm{~atm}$. The most likely reason consists in the fact that water molecules inhibit the active electrochemical centres of oxygen ions or participating molecules (steps 4-7), as has been shown in many independent studies [50-52].

Finally, the intensity of the high frequency peak (more than $10^{4.5} \mathrm{~Hz}$ ) also decreases with increases in the applied voltage (Fig. 5). Such a frequency range corresponds to the mass and charge transfer through the interfaces (steps 8-11). It should be mentioned that air humidification results in unexpected increasing the peak's intensity (Fig. A3). This might be associated with the dual (co-ionic) nature of the electrolyte and electrode systems [53], when not only proton charge transfer, but also oxygen charge transfer occurs. Therefore, the increased $\mathrm{pH}_{2} \mathrm{O}$ is accompanied by suppressed oxygen transport, which dominates over the protonic transport in PBN and, therefore, increases the electrode resistance.

On the base of the DRT analysis, the absolute values of $R_{1}, R_{2}$, $R_{3}$, as well as their respective contributions, were plotted against $T$ and $U$ (Fig. 6). As can be clearly distinguished, the low frequency resistance $\left(R_{3}\right)$ determines the total polarisation resistance of the electrodes at low T and $U$, while the high-frequency resistance $\left(R_{1}\right)$ dominates over $R_{2}$ and $R_{3}$ at other boundary conditions. Generally, monotonous tendencies are observed with gradual variation of external parameters despite of some exceptions $\left(R_{2}\right.$ at $500{ }^{\circ} \mathrm{C}$ under OCV, $R_{3}$ at $600{ }^{\circ} \mathrm{C}$ and $1.3 \mathrm{~V}$ ). In this regard, we should mention that the studied PCEC exhibits a high electrode area in which the current distribution is not ideal compared with that of smaller cells. Therefore, some observed deviations might be derived from non-uniform concentration distribution of gas components along the diameter and length of the tube as well as local differences in the electrochemical parameters (electrical voltage difference, current).

Fig. 7 shows the polarisation resistance of the electrodes (as a sum of $R_{1}, R_{2}, R_{3}$ components) calculated from the DRT results, ohmic resistance of the electrolyte $\left(R_{0}\right)$ determined as the highfrequency intercept of the impedance spectra with the axis of real resistances, resulting total resistance of the cell $\left(R_{\text {total }}=R_{\mathrm{O}}+R_{p}\right)$ and their ratio. As can be seen, all the constituent components decrease with increases both in temperature and applied voltage, which is in line with well-reproducible results obtained for protonic ceramic electrochemical cells [37,54]. At the same time, the $R_{p} / R_{\text {total }}$ ratio decreases rapidly, indicating that the polarisation resistance (related primarily to the electrochemical performance of the $\operatorname{Pr}_{1.95} \mathrm{Ba}_{0.05} \mathrm{NiO}_{4+\delta}$ anode) dominates only at $500{ }^{\circ} \mathrm{C}$; at higher temperatures, it shows promising values exceeding those 


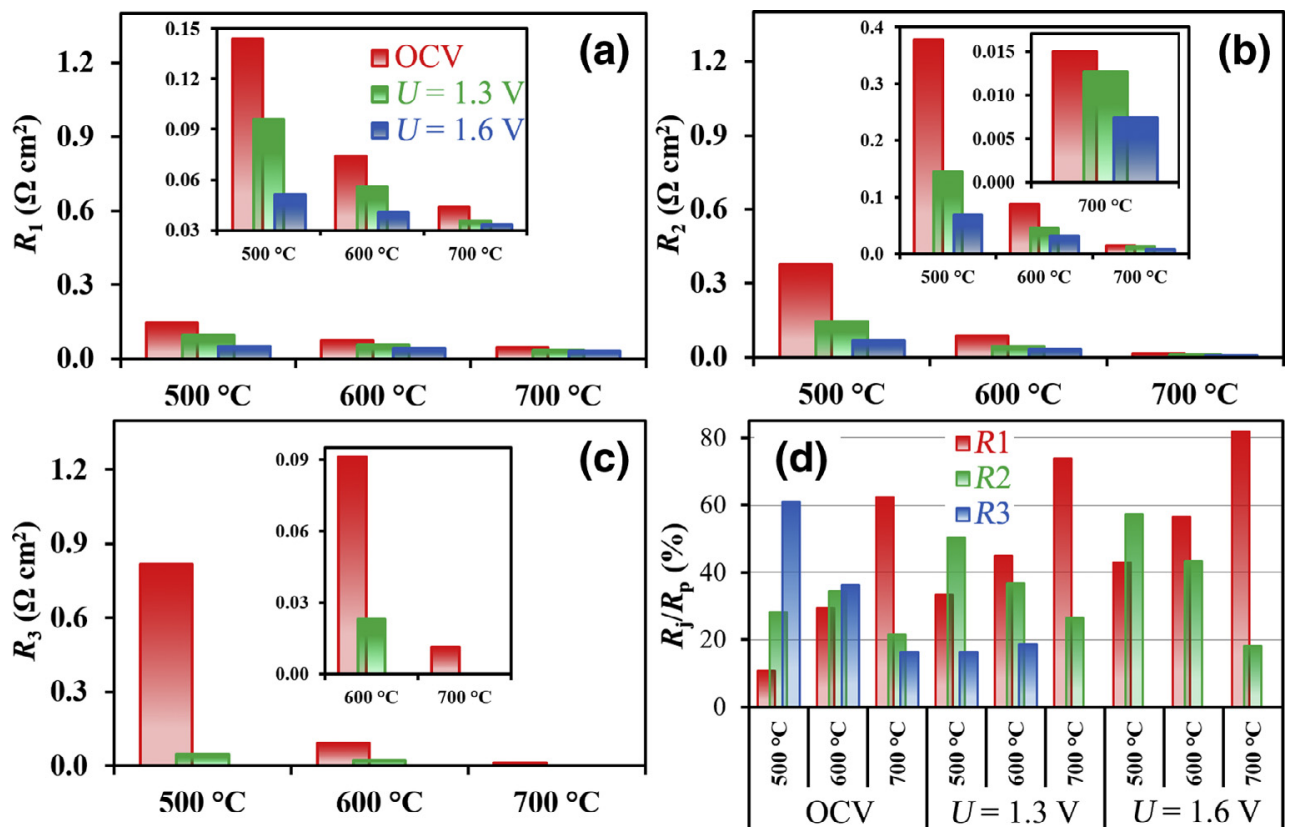

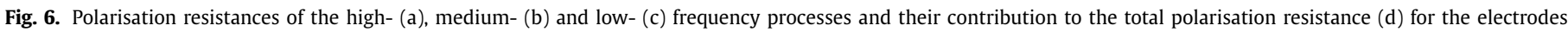
of the fabricated PCEC at different temperatures and biases. Insets: the same data on an enlarged scale.
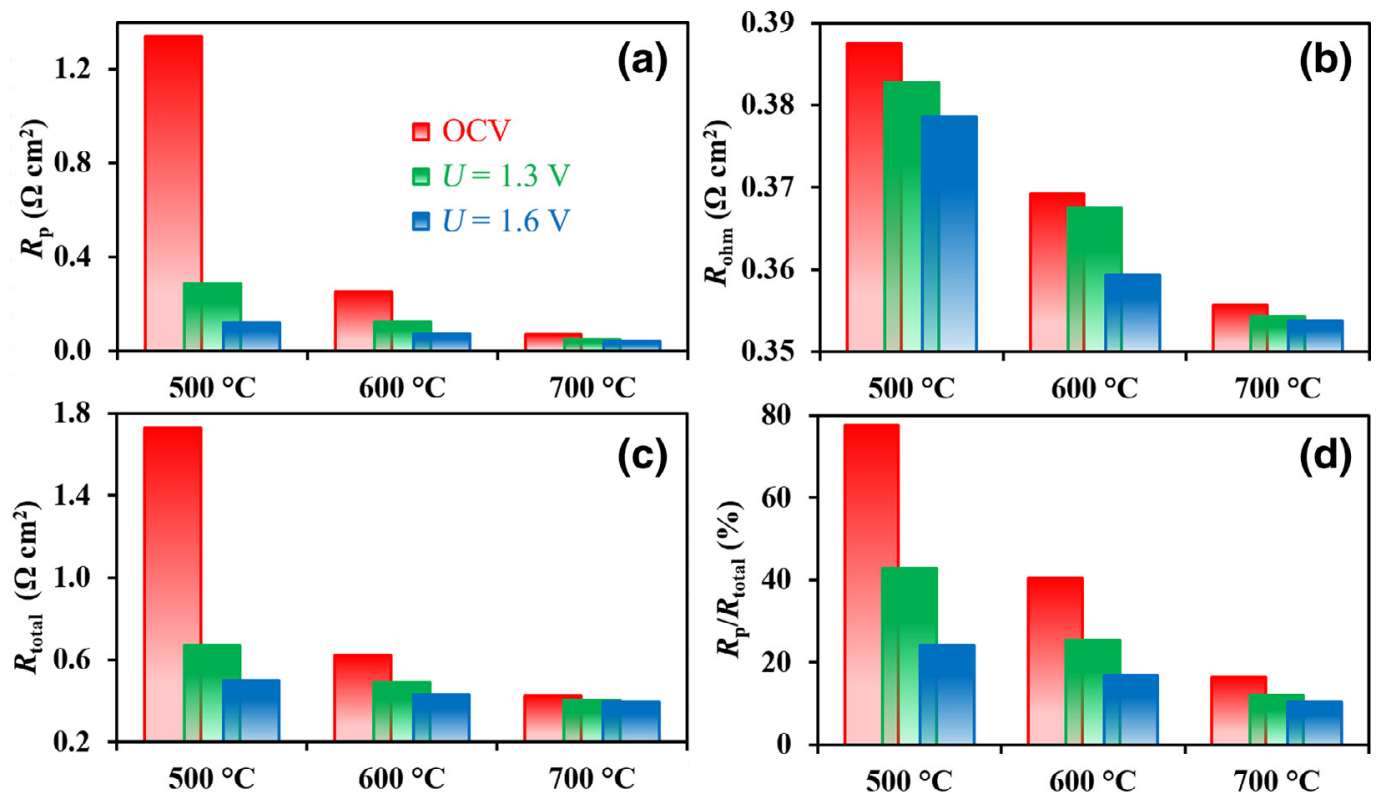

Fig. 7. Polarisation (a), ohmic (b), total (c) resistances and their relation (d) for the fabricated PCEC at different temperatures and biases.

for PCFCs and PCECs based on $\mathrm{Ln}_{2} \mathrm{NiO}_{4+\delta}$ electrodes (Table 4 $[12-14,17,23,55,56])$. From this viewpoint, the Ba-modification of the basic $\mathrm{Ln}_{2} \mathrm{NiO}_{4}$ structure can be considered as an effective tool for designing the oxygen electrode materials, since having not only excellent chemical and thermal compatibility with the protonconducting electrolytes, but also excellent electrochemical activity in environments with the increased humidity, while some other examples of electrodes demonstrate strongly negative characteristics in cases of increased $\mathrm{pH}_{2} \mathrm{O}$ [53].

\subsubsection{Long-term operability}

The fabricated cell was tested in electrolysis mode at $600{ }^{\circ} \mathrm{C}$ to evaluate its performance behaviour under a short-time period (Fig. 8). The initial current density amounts to $611 \mathrm{~mA} \mathrm{~cm}^{-2}$ when a constant bias of $1.3 \mathrm{~V}$ is applied to the cell. The current density

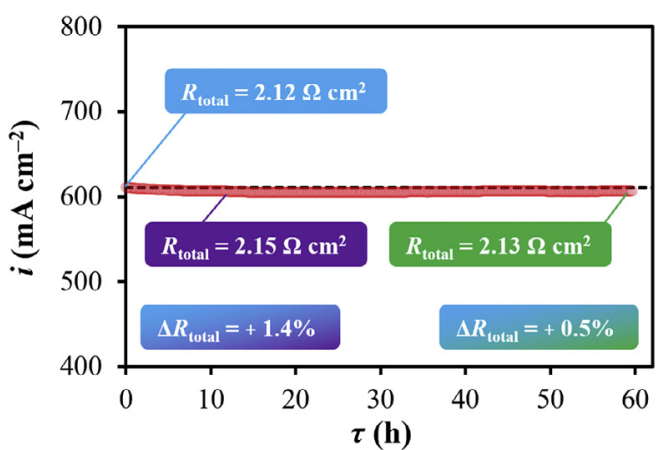

Fig. 8. Long-term stability of the PCEC at $600{ }^{\circ} \mathrm{C}$ and $U_{\text {tn }}$ under potentiostatic measurements. 
Table 4. Overall electrode performance for PCFCs or PCECs under OCV mode of operation at $600{ }^{\circ} \mathrm{C}$.

\begin{tabular}{|c|c|c|c|}
\hline Electrolyte & Oxygen electrode $^{\mathrm{a}}$ & $R_{\mathrm{p}}\left(\Omega \mathrm{cm}^{2}\right)$ & Ref. \\
\hline $\mathrm{BaCe}_{0.5} \mathrm{Zr}_{0.3} \mathrm{Dy}_{0.2} \mathrm{O}_{3-\delta}$ & $\mathrm{Pr}_{1.95} \mathrm{Ba}_{0.05} \mathrm{NiO}_{4+\delta}{ }^{\mathrm{b}}$ & 0.25 & This work \\
\hline $\mathrm{BaCe}_{0.55} \mathrm{Zr}_{0.3} \mathrm{Y}_{0.15} \mathrm{O}_{3-\delta}$ & $\mathrm{Pr}_{2} \mathrm{NiO}_{4+\delta}$ & 0.28 & 12 \\
\hline $\mathrm{BaCe}_{0.7} \mathrm{Zr}_{0.1} \mathrm{Y}_{0.2} \mathrm{O}_{3-\delta}$ & $\mathrm{La}_{2} \mathrm{NiO}_{4+\delta}$ & 0.96 & 13 \\
\hline $\mathrm{BaCe}_{0.7} \mathrm{Zr}_{0.1} \mathrm{Y}_{0.2} \mathrm{O}_{3-\delta}$ & $\mathrm{La}_{2} \mathrm{NiO}_{4+\delta}-\mathrm{LaNi}_{0.6} \mathrm{Fe}_{0.4} \mathrm{O}_{3-\delta}$ & 0.49 & 13 \\
\hline $\mathrm{BaCe}_{0.4} \mathrm{Zr}_{0.4} \mathrm{Y}_{0.2} \mathrm{O}_{3-\delta}$ & $\mathrm{Pr}_{2} \mathrm{NiO}_{4+\delta}$ & 1.00 & 14 \\
\hline $\mathrm{BaCe}_{0.2} \mathrm{Zr}_{0.6} \mathrm{Y}_{0.2} \mathrm{O}_{3-\delta}$ & $\mathrm{Pr}_{2} \mathrm{NiO}_{4+\delta}-\mathrm{BaCe}_{0.2} \mathrm{Zr}_{0.6} \mathrm{Y}_{0.2} \mathrm{O}_{3-\delta}$ & 0.75 & 17 \\
\hline $\mathrm{BaCe}_{0.7} \mathrm{Zr}_{0.1} \mathrm{Y}_{0.2} \mathrm{O}_{3-\delta}$ & $\mathrm{Pr}_{1.2} \mathrm{Sr}_{0.8} \mathrm{NiO}_{4+\delta}$ & 2.17 & 23 \\
\hline $\mathrm{BaCe}_{0.7} \mathrm{Zr}_{0.1} \mathrm{Y}_{0.2} \mathrm{O}_{3-\delta}$ & $\mathrm{La}_{1.2} \mathrm{Sr}_{0.8} \mathrm{NiO}_{4+\delta}$ & 1.47 & 23 \\
\hline $\mathrm{BaCe}_{0.89} \mathrm{Gd}_{0.2} \mathrm{Cu}_{0.01} \mathrm{O}_{3-\delta}$ & $\mathrm{Pr}_{1.7} \mathrm{Ca}_{0.3} \mathrm{NiO}_{4+\delta}-\mathrm{BaCe}_{0.89} \mathrm{Gd}_{0.2} \mathrm{Cu}_{0.01} \mathrm{O}_{3-\delta}{ }^{\mathrm{b}}$ & 1.86 & 55 \\
\hline $\mathrm{BaCe}_{0.9} \mathrm{Y}_{0.1} \mathrm{O}_{3-\delta}$ & $\mathrm{Pr}_{2} \mathrm{NiO}_{4+\delta}$ & 2.76 & 56 \\
\hline
\end{tabular}

a Fuel electrodes represent Ni-based cermets, which might consist of functional and supported layers;

b The $\mathrm{LaNi}_{0.6} \mathrm{Fe}_{0.4} \mathrm{O}_{3-\delta}$ current collector was used.

decreases down to $605 \mathrm{~mA} \mathrm{~cm}{ }^{-2}$ during the first ten hours, but then relaxes gradually until reaching a stable level $\left(609 \mathrm{~mA} \mathrm{~cm}^{-2}\right)$. In terms of the total cell resistance, its increment is $\sim 0.5 \%$ per $60 \mathrm{~h}$. Although the degradation rate related with $1000 \mathrm{~h}$ is estimated as rather tangible $(\sim 8 \%)$, the future design of electrode systems and selection of appropriate working conditions can provide a possible solution to this problem. A prime example of such strategies can be found in the series of works by Dailly and Marrony $[57,58]$, in which the degradation rate was decreased to $5 \% / 1000 \mathrm{~h}$ for a protonic ceramic electrochemical cell operated in electrolysis mode.

\section{Conclusions}

In this work, a tubular-type protonic ceramic electrolysis cell (PCEC) was fabricated for the first time utilising a tape-calendering (TC) method and then comprehensively characterised using voltampere measurements, electrochemical impedance spectroscopy and distribution of relaxation time analyses. The cheapness and technological simplicity of the TC method allowed electrode surface areas as high as $4.6 \mathrm{~cm}^{2}$ to be achieved for a single cell, which could yield hydrogen flux values of 12,19 and $25 \mathrm{~mL} \mathrm{~min}^{-1}$ at 500 , 600 and $700{ }^{\circ} \mathrm{C}$, respectively. The excellent integrity and performance of the PCEC was determined by a rational choice of the functional materials used. In detail, both electrodes of the PCEC were based on nickel: Ni-cermet as a cathode, $\operatorname{Pr}_{1.95} \mathrm{Ba}_{0.05} \mathrm{NiO}_{4+\delta}$ (PBN) as an anode and $\mathrm{LaNi}_{0.6} \mathrm{Fe}_{0.4} \mathrm{O}_{3-\delta}$ as a current collector. Utilisation of the tape-calendering method for creating the multilayered structures on one side and Ni-based materials with excellent compatibility and electrochemical activity on the other can be considered as promising potential technological approaches for scaling and industrialisation of solid oxide electrochemical cells, including ones based on proton-conducting materials.

Although here we have presented results regarding water electrolysis in the PCEC, similar materials can also be used for carrying out $\mathrm{CO}_{2}$ electrolysis and related electrochemical reforming processes [59-61]. In detail, $\mathrm{Ln}_{2} \mathrm{NiO}_{4+\delta}$-based nickelates exhibit excellent $\mathrm{CO}_{2}$-tolerance [62-64], while an appropriate stability of the $\mathrm{Ba}(\mathrm{Ce}, \mathrm{Zr}) \mathrm{O}_{3}$ proton-conducting electrolytes can be achieved by increasing the $\mathrm{Zr} / \mathrm{Ce}$ ratio [24,26].

\section{Acknowledgments}

This work was supported by the Russian Foundation for Basic Research (grant no. 18-38-20063). Dr. D. Medvedev is grateful to the Council of the President of the Russian Federation (scholarship no. CП-161.2018.1) for supporting the studies devoted to new MIEC materials. Other sections are performed within the framework of the budgetary plans of the Institute of High Temperature Electrochemistry.
The characterisation of powder and ceramic materials was carried out at the Shared Access Centre "Composition of Compounds" of the Institute of High Temperature Electrochemistry [27].

\section{Appendix A}

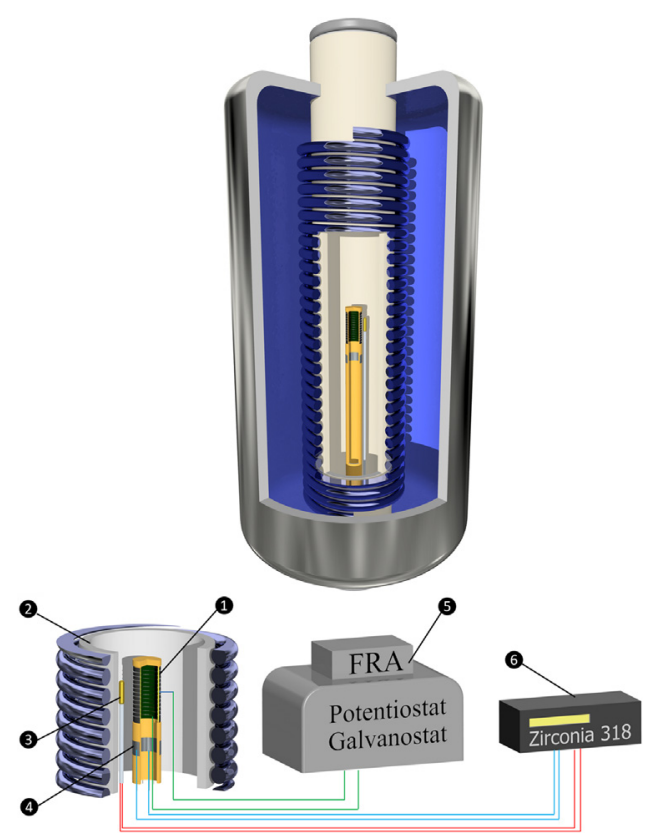

Fig. A1. Principle scheme of the electrochemical cell testing for carrying out water electrolysis process: 1 - the tubular PCEC, 2 - oven, 3 - thermocouple, 4 - oxygen sensor, 5 - potentiostat/galvanostat station coupled with FRA, 5 - microprocessor system for setting and monitoring $\mathrm{T}$ and $\mathrm{pO}_{2}$.

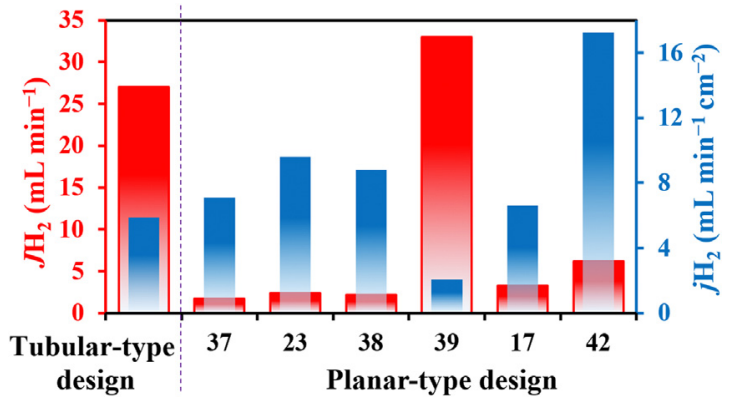

Fig. A2. Performance of the fabricated PCEC with those of the planar-type ones at $700{ }^{\circ} \mathrm{C}$ and the conditions close to $\mathrm{U}_{\mathrm{tn}}$. 

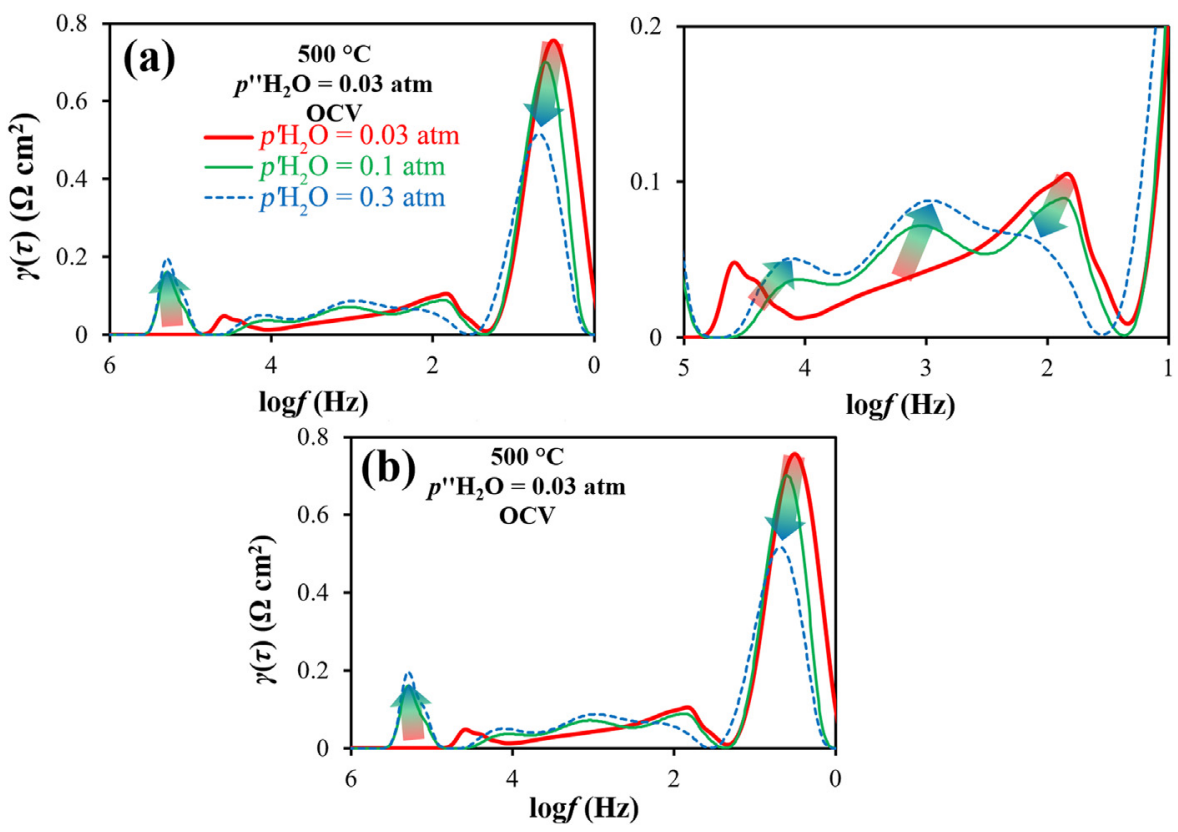

Fig. A3. Frequency-dependent DRT as a function of water vapor partial pressure at the anode side at $500{ }^{\circ} \mathrm{C}(\mathrm{a})$ and $700{ }^{\circ} \mathrm{C}(\mathrm{b})$.

\section{Supplementary material}

Supplementary material associated with this article can be found, in the online version, at doi:10.1016/j.jechem.2019.02.014.

\section{References}

[1] H. Zhao, Q. Li, L. Sun, Sci. Chin. Chem. 54 (2011) 898-910.

[2] F. Mauvy, J.-M. Bassat, E. Boehm, J.-P. Manaud, P. Dordor, J.-C. Grenier, Solid State Ion. 158 (2003) 17-28

[3] V. Vibhu, A. Rougier, C. Nicollet, A. Flura, J.-C. Grenier, J.-M. Bassat, Solid State Ion. 278 (2015) 32-37.

[4] G. Yang, C. Su, R. Ran, M.O. Tade, Z. Shao, Energy Fuels 28 (2014) 356-362.

[5] C. Ferchaud, J.-C. Grenier, Y. Zhang-Steenwinkel, M.A. van Tuel, Marc van Frans, P.F. Berkel, J.-M. Bassat, J. Power Sources 196 (2010) 1872-1879.

[6] E. Yu. Pikalova, D.A. Medvedev, A.F. Khasanov, Phys. Solid State 59 (2017) 694-702.

[7] Yu.G. Lyagaeva, N.A. Danilov, M.Yu. Gorshkov, G.K. Vdovin, B.D. Antonov, A.K. Demin, D.A. Medvedev, Russ. J. Appl. Chem. 91 (2018) 583-590.

[8] V.V. Kharton, A.V. Kovalevsky, M. Avdeev, E.V. Tsipis, M.V. Patrakeev, A.A. Yaremchenko, E.N. Naumovich, J.R. Frade, Chem. Mater. 19 (8) (2007) 2027-2033.

[9] D. Lee, H.N. Lee, Materials 10 (4) (2017) 368

[10] S.J. Skinner, J.A. Kilner, Solid State Ion. 135 (2000) 709-712.

[11] V.A. Sadykov, E.M. Sadovskaya, E. Yu, Pikalova, A.A. Kolchugin, E.A. Filonova, S.M. Pikalov, N.F. Eremeev, A.V. Ishchenko, A.I. Lukashevich, J.M. Bassat, Ionics 24 (2018) 1181-1193.

[12] H. An, D. Shin, H.-I. Ji, J. Korean Ceram. Soc. 24 (2018) 1181-1193.

[13] J. Hou, Z. Zhu, J. Qian, W. Liu, J. Power Sources 264 (2014) 67-75.

[14] N. Nasani, D. Ramasamy, S. Mikhaleva, A.V. Kovalevsky, D.P. Fagg, J. Power Sources 278 (2015) 582-589.

[15] H. Tang, Z. Gong, Y. Wu, Z. Jin, W. Liu, Int. J. Hydrogen Energy 43 (2018) 19749-19756.

[16] A. Grimaud, F. Mauvy, J.M. Bassat, S. Fourcade, L. Rocherona, M. Marrony, J.C. Grenier, J. Electrochem. Soc. 159 (2012) B683-B694.

[17] W. Li, B. Guan, L. Ma, S. Hu, N. Zhanga, X. Liu, J. Mater. Chem. A 6 (2018) 18057-18066.

[18] A. Grimaud, F. Mauvy, J.M. Bassat, S. Fourcade, M. Marrony, J.C. Grenier, J. Mater. Chem. 22 (2012) 16017-16025.

[19] Y. Zheng, J. Wang, B. Yu, W. Zhang, J. Chen, J. Qiao, J. Zhang, Chem. Soc. Rev. 46 (2017) 1427-1463.

[20] N. Danilov, J. Lyagaeva, G. Vdovin, D. Medvedev, Appl. Energy 237 (2019) 924-934.

[21] S.M. Babiniec, S. Ricote, N.P. Sullivan, Int. J. Hydrogen Energy 40 (2015) 9278-9286.

[22] A. Tarutin, J. Lyagaeva, A. Farlenkov, S. Plaksin, G. Vdovin, A. Demin, D. Medvedev, Materials 12 (1) (2019) 118.

[23] S. Yang, Y. Wen, J. Zhang, Y. Lu, X. Ye, Z. Wen, Electrochim. Acta 267 (2018) 269-277.

[24] N. Danilov, A. Tarutin, J. Lyagaeva, G. Vdovin, D. Medvedev, J. Mater. Chem. A. 6 (2018) 16341-16346.
[25] J. Lyagaeva, D. Medvedev, E. Pikalova, S. Plaksin, A. Brouzgou, A. Demin, P. Tsiakaras, Int. J. Hydrogen Energy 42 (2017) 1715-1723.

[26] N.A. Danilov, J.G. Lyagaeva, D.A. Medvedev, A.K. Demin, P. Tsiakaras, Electrochim. Acta 284 (2018) 551-559.

[27] http://www.ihte.uran.ru/?page id=3142.

[28] D. Medvedev, J. Lyagaeva, G. Vdovin, S. Beresnev, P.Tsiakaras A.Demin, Electrochim. Acta 210 (2016) 681-688.

[29] T. Norby, Solid State Ion. 28-30 (1988) 1586-1591.

[30] D.P. Sutija, T. Norby, P. Björnbom, Solid State Ion. 77 (1995) 167-174.

[31] H.-I. Ji, B.-K. Kim, J.H. Yu, S.-M. Choi, H.-R. Kim, J.-W. Son, H.-W. Lee, J.-H. Lee, Solid State Ion. 203 (2011) 9-17.

[32] G. Heras-Juaristi, D. Pérez-Coll, G.C. Mather, J. Power Sources 364 (2017) $52-60$.

[33] N. Kochetova, I. Animitsa, D. Medvedev, A. Demin, P. Tsiakaras, RSC Adv. 6 2016) 73222-73268.

[34] D. Huan, W. Wang, Y. Xie, N. Shi, Y. Wan, C. Xia, R. Peng, Y. Lu, J. Mater. Chem. A. 6 (2018) 18508-18517.

[35] S.D. Ebbesen, S.H. Jensen, A. Hauch, M.B. Mogensen, Chem. Rev. 114 (2014) 10697-10734

[36] M.A. Laguna-Bercero, J. Power Sources 2013 (2012) 4-16.

[37] D. Huan, N. Shi, L. Zhang, W. Tan, Y. Xie, W. Wang, C. Xia, R. Peng, Y. Lu, ACS Appl. Mater. Interfaces 10 (2018) 1761-1770.

[38] S. Yang, Y. Lu, Q. Wang, Ce. Sun, X. Ye, Z. Wen, Int. J. Hydrogen Energy 43 (2018) 20050-20058.

[39] M. Marrony, M. Ancelin, G. Lefevre, J. Dailly, Solid State Ion. 275 (2015) 97-100.

[40] K. Leonard, Y. Okuyama, Y. Takamura, Y.-S. Lee, K. Miyazaki, M.E. Ivanova, W.A. Meulenberge, H. Matsumoto, J. Mater. Chem. A. 6 (2018) 19113-19124.

[41] L. Lei, Z. Tao, X. Wang, J.P. Lemmond, F. Chen, J. Mater. Chem. A. 5 (2017) $22945-22951$.

[42] J. Kim, A. Jun, O. Gwon, S. Yoo, M. Liu, J. Shin, Lim T.-H, G. Kim, Nano Energy 44 (2018) 121-126.

[43] M.K. Stodolny, B.A. Boukamp, D.H.A. Blank, F.P.F. van Berkel, J. Power Sources 196 (2011) 6290-9298.

[44] G. Gregori, R. Merkle, J. Maier, Prog. Mater. Sci. 89 (2017) 252-305.

[45] B.A. Boukamp, A. Rolle, Solid State Ion. 314 (2018) 103-111.

[46] B.A. Boukamp, A. Rolle, Solid State Ion. 302 (2017) 12-18.

[47] N. Shi, F. Su, D. Huan, Y. Xie, J. Lin, W. Tan, R. Peng, C. Xia, C. Chena, Y. Lu, J. Mater. Chem. A 5 (2017) 19664-19671.

[48] X. Wang, Z. Ma, T. Zhang, J. Kang, X. Ou, P. Feng, S. Wang, F. Zhou, Y. Ling, ACS Appl. Mater. Interfaces 10 (2018) 35047-35059.

[49] S. Sun, Z. Cheng, J. Electrochem. Soc. 164 (2017) F3104-F3113.

[50] R.S. Vladimir, A. Cherepanov, A.Y. Zuev, D.S. Tsvetkov, C. Argirusis, G. Sourkouni, S. Prünte, T. Norby, Solid State Ion. 278 (2015) 120-132.

[51] E.P. Antonova, A.A. Kolchugin, E.Y. Pikalova, D.A. Medvedev, N.M. Bogdanovich, Solid State Ion. 306 (2017) 55-61.

[52] S. Sun, Z. Cheng, J. Electrochem. Soc. 164 (2017) F81-F88.

[53] W. Wang, D. Medvedev, Z. Shao, Adv. Funct. Mater. 28 (2018) 1802592

[54] Y. Gan, J. Zhang, Y. Li, S. Li, K. Xie, J.T.S. Irvine, J. Electrochem. Soc. 159 (2012) F763-F767.

[55] E. Pikalova, A. Kolchugin, N. Bogdanovich, D. Medvedev, J. Lyagaeva, L. Vedmid, M. Ananyev, S. Plaksin, A. Farlenkov, Int. J. Hydrogen Energy (2018) In presshttps://doi.org/10.1016/j.ijhydene.2018.06.023. 
[56] G. Taillades, J. Dailly, M. Taillades-Jacquin, F. Mauvy, A. Essouhmi, M. Marrony, C. Lalanne, S. Fourcade, D.J. Jones, J.C. Grenier, J. Rozière, Fuel Cells 10 (2010) 166-173.

[57] J. Dailly, M. Ancelin, M. Marrony, Solid State Ion. 306 (2017) 69-75.

[58] J. Dailly, M. Marrony, J. Power Sources 240 (2013) 323-327.

[59] X. Zhang, Y. Song, G. Wang, X. Bao, J. Energy Chem 26 (2017) 839-853.

[60] L. Zhang, S. Hu, X. Zhu, W. Yang, J. Energy Chem. 26 (4) (2017) 593-601.
[61] N. Shi, Y. Xie, D. Huan, Y. Yang, S. Xue, Z. Qi, Y. Pan, R. Peng, C. Xia, Y. Lu, J. Mater. Chem. A. 7 (2019) 4855-4864.

[62] G. Li, H. Jin, L. Gui, B. He, L. Zhao, Int. J. Hydrogen Energy 43 (2018) 3291-3298.

[63] Q. Wei, S. Zhang, B. Meng, N. Han, Z. Zhu, S. Liu, Mater. Lett. 230 (2018) $161-165$.

[64] J. Cheng, S. Zhang, B. Meng, J. Ding, X. Tan, J. Alloys Compd. 742 (2018) 966-976. 